Research Article

\title{
New Host Record of Lutjanus gibbus for Parasitic Nerocila sp. (Crustacea, Isopoda, Cymothoidae) from South Andaman, Andaman Islands, India
}

\author{
Anil Pathan *, Paul Sayeri, Kadeparambil Arjunan Jayaraj \\ Department of Ocean Studies and Marine Biology, School of Life Sciences, Pondicherry University, Andaman \\ Islands 744112, India
}

Article history:

Submission January 2019

Revised March 2019

Accepted August 2019

*Corresponding author:

E-mail: anil.federer070@gmail.com

\begin{abstract}
A new host of Cymothoid isopod, Nerocila sp. was identified from the dorsal surface of the body (caudal peduncle) of Lutjanidae fish Lutjanus gibbus (Forsskal, 1775) which is a new host record of isopod parasite Nerocila sp. from the coastal waters of South Andaman, Andaman Islands. This study revealed the first occurrence of this parasitic isopod (Nerocila sp.) from Andaman and Nicobar Islands. A comprehensive summary of the nominal Nerocila species recorded on different host species is provided. The present finding adds another species of isopod to the checklist of Andaman and Nicobar Islands.
\end{abstract}

Keywords: New host, Lutjanus gibbus, Isopod parasite, Nerocila sp., South Andaman, India

\section{Introduction}

There are many crustacean parasites on fishes in marine, fresh, and brackish water, and most of them are found in natural fish populations [1]. Parasites play an important role in the biology of fishes and can affect their behavior, health and distribution [2]. The order Isopoda are classified into 12 suborders among which the suborder $\mathrm{Cy}$ mothoida includes 29 families, out of which, the family Cymothoidae included 43 genera and 358 species [3]. Cymothoidae isopods are one of the most recognizable groups of isopods to fisherman and anglers [4]. The members of Cymothoidae are ectoparasitic isopods of dominant marine fishes [5] and the greatest diversity being in tropical marine environments [6]. Both in the tropical and temperate waters, these parasitic isopods infect numerous species of fishes of commercial importance. Like most isopods, cymothoids feed principally on host blood, but they may also consume mucus, epithelium and subcutaneous tissues of their hosts [7]. Several species attach to the buccal cavity, in the gill chambers, on the body surface and fins [8]. They are important parasites to many commercial fish, which can cause damage to various ranges to the fisheries resources [9].

Nerocila Leach, 1818 is the largest genus in the family Cymothoidae and includes around 65 species of fish parasites reported from different parts of the world on different host species [10]. In the present study, we reported for the first time a new host record of the fish Lutjanus gibbus infected by the isopod parasite Nerocila sp. from the coastal waters of South Andaman and this genus (Nerocila) is first time report from these Islands.

\section{Material and Methods}

The host fish species L. gibbus was collected from Junglighat fish landing center (Lat.11³9'25.09"N; Long. 9243'30.35"E), South Andaman in July, 2018 (Figure 1). The host fish species were captured by gill nets operation in coastal waters of South Andaman. Generally, gill nets and trawlers are operated in the near shore area for fishing. Identification of host fish was based on FAO key [11]. The sampling date, locality, host fish, and site of attachment on the host fish were recorded. The parasite was gently pulled

\section{How to cite:}

Pathan A, Sayeri P, Jayaraj KA (2019) New Host Record of Lutjanus gibbus for Parasitic Nerocila sp. (Crustacea, Isopoda, Cymothoidae) from South Andaman, Andaman Islands, India. Journal of Tropical Life Science 9 (3): 217 - 222. doi: 


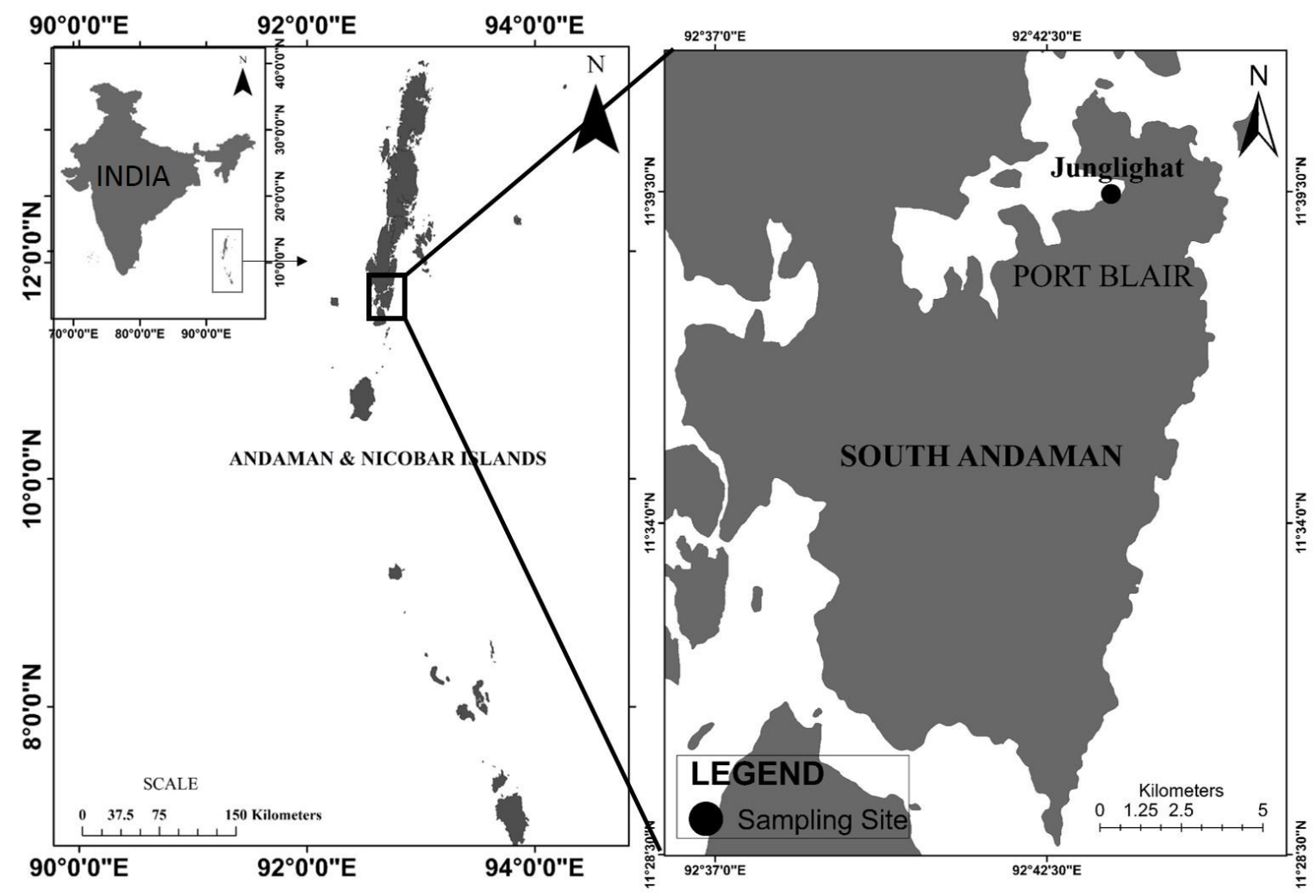

Figure 1. Map showing the study area

up from the caudal peduncle of host body, with the help of forceps and immediately preserved in 70\% ethanol. The isopod was identified, using a dissecting microscope (Olympus BX 41) and a stereomicroscope (Nikon SMZ 1500) according to Bruce (1987). The specimen of the collected parasitic isopod was preserved and deposited in the collections of Museum in Department of Ocean Studies and Marine Biology, Pondicherry University, Port Blair, India (PUMB 3530, TL 20 mm).

\section{Results and Discussion \\ Taxonomy}

Class : Malacostraca

Order : Isopoda

Family : Cymothoidae Leach, 1814

Genus : Nerocila Leach, 1818

\section{Material examined}

L. gibbus (Lutjanidae) was parasitized by a single specimen of Nerocila sp. on the caudal peduncle. Host fish samples were collected from Junglighat fish landing centre (Lat.1139'25.09"N; Long. 92 43 '30.35"E), South Andaman in July, 2018, coll. Pathan Anil. The parasite Nerocila sp. was found attached to the caudal peduncle of the body, facing towards the head of the host fish (Figure 2).

\section{Measurements}

Total length: $20 \mathrm{~mm}$; Width: $0.08 \mathrm{~mm}\left(6^{\text {th }}\right.$ perionite); Length of antennule: $0.02 \mathrm{~mm}$; Length of antenna: slightly less than $0.02 \mathrm{~mm}$; Length of pleotelson: $0.04 \mathrm{~mm}$; Length of exopod: $0.04 \mathrm{~mm}$ and endopod: $0.02 \mathrm{~mm}$.

\section{Description}

Body is longer than wide, dorsoventrally flattened. Cephalon anterior margin conical shaped, posterior margin distinctly trilobed. A pair of sessile eyes on the dorsal side of the cephalon but these eyes is not clearly visible (Figure 3). 2 distinct antennae. Antenna 1 is slightly longer than antenna 2 and stout with 8 articles, articles 1 and 2 conspicuously larger than 3-8 articles. 7 perionites with 6th being the widest. Coxae is not well developed it is slightly appearance of dorsal view. 7 pairs of uniramous periopods having marginal spines and terminal claw like structure. Pleon manifestly narrower than pereon; ventrolateral margins of pleonites 1 and 2 produced. Endopods of pleopods 1-5 with accessory lamella on proxi- 


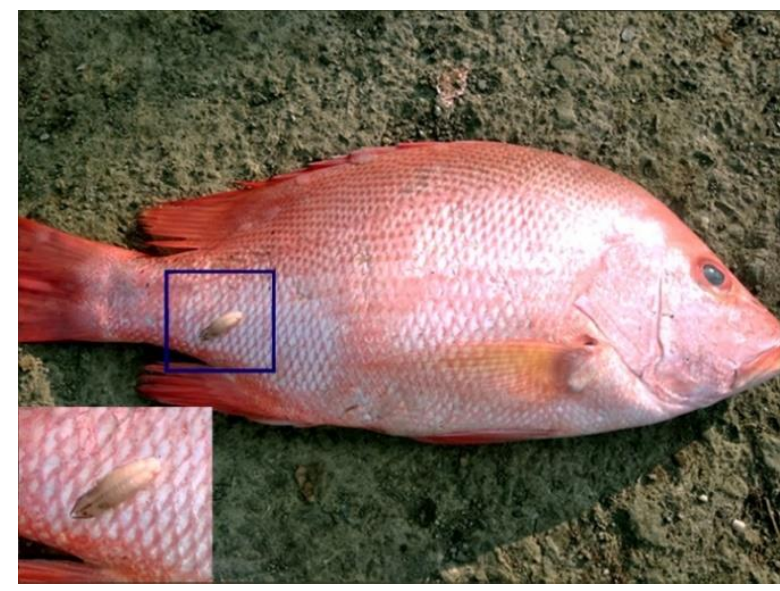

Figure 2. Isopod parasite Nerocila sp. on the host fish L. gibbus

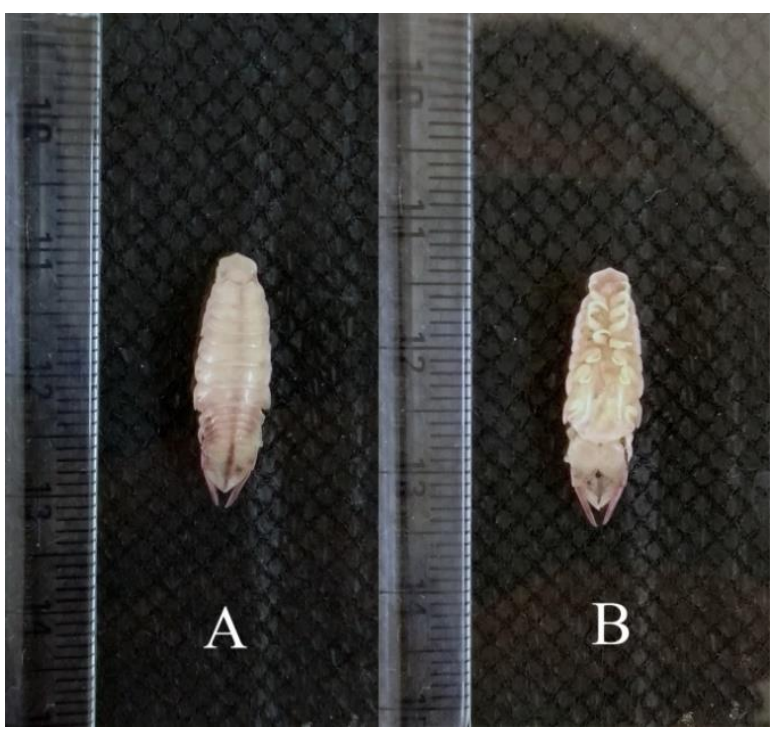

Figure 3. Dorsal (A) and ventral (B) view of Nerocila sp.

momedial margin, becoming large and folded on pleopods 3-5. Uropod exopod it is longer than endopod it is reaching well beyond the pleotelson tip; straight margins converging to narrowly rounded tip. Endopod of uropod it is reaching slightly beyond the pleotelson tip. Pleotelson flat and posterior margin rounded.

\section{Colour}

Whitish brown on dorsal surface. Dark strip along mid line of the body, continued up to the posterior region of the pleotelson.

\section{Remarks}

The present collected specimen morphologically exhibits slight appearance of genus Ambly- cephalon reported by Pillai (1954). In Amblycephalon, ventrolateral margins of pleonites 1 and 2 is not produced and coxae conspicuous in dorsal view. But, in present collected specimen, the ventrolateral margins of pleonites 1 and 2 were produced and coxae are not well developed and appear slightly in dorsal view of organism.

Cymothoid isopods have been mentioned in some of the earliest references on natural history, but despite this long history, in many parts of the world they are still incompletely known or even completely unknown [14]. The work on parasitic isopod in Andaman and Nicobar Islands is very scanty. Only few reports are available on the distribution of parasitic isopods on marine fishes from Andaman Islands [15, 16, 17]. According to literature in these Andaman Islands, under the family Cymothoidae, only 6 genera are reported viz, Pleopodius, Renocila, Norileca, Cymothoa, Joryma, and Ryukyua. Regarding the genus Nerocila, there is no previous report from Andaman Islands. In the present study, we reported new host record of the fish $L$. gibbus infected by the isopod parasite Nerocila sp. for the first time and this parasitic specimen was collected from caudal peduncle of the host fish.

The genus Nerocila associate with many species of commercially important fishes around the world and cause significant economic losses to fisheries by killing, stunting or damaging [3]. Till now, the genus Nerocila was reported from different host species viz, Lates calcarifer, Lobotes surinamensis, Pellona ditchella, Mugil georgii, Carangoides humerosus, Lutjanus sp., Nemipterus hexodon, Pomadasys hasta, Priacanthus macracanthus, Acanthopagrus australis, Chrysophrys auratus, Rhabdosargus sarba, Callorhynchus milii, Pseudocaranx dentex, Dactylopena orientalis, Girella tricuspidata, Mola mola, Pomatomus saltatrix, Sillago bassensis, Acanthopagrus butcheri, Chelidonichthye kumu, Liza argentea, Engraulis australis and Cnidoglanus macrocephalus [12], Coilia dussumieri, Cyclocheilichthyes apogon, Opisthopterus turtoor, Sardinella fimbriata, Scomberomorus multiradiatus, Leiognathus sp., Sardinops melanosticta, Illisha melastoma, Engraulis japonica, Parastromateus niger, Sciaenia dussumieri, Argyrosoma hololepidotus, A. macrocephalus, A. nibe, Pomadasys sp., Siganus orami, Epinephilus tauvina, Acanthopagrus latus, Nemipterus japoni- 
cus, N. tolu, Sciaena sp., Eleutheronema sp., Mugil sp. and Exocoetus volitans [18], Spratelle kowale, Spratelle tembang, Chirocentrus dorab, Xiphias gladius, Sardinella gibbosa, S. perforate, Dussumieria hasselti, Decapterus maruadsi, Sardinella zunasi, Scomberomorus sp., Polydactylus sp., Ilisha indica, Helotes sexlineatus, Acanthopagrus cuvieri, Pelates quadrilineatus, Kathala axillaris and Siganus oramin [19], Priacanthus arenatus, Heteropriacanthus cruentatus [20], Carangoids malbaricus, Selaroids leptolepis, Dussumieria acuta, Sardinella brachysoma, Sardinella longiceps, Sardinella sindensis, Tenulosa ilisha, Stolephorus commersonnii, Thryssa dussumieri, Thryssa mystax, Istiophorus platypterus, Rastrelliger kanagurta, Scomberomous guttatus, Arius jella, Gazza minuta, Leiognathus splendens and Sphyraena jello [6,21], Thryssa mystax, Trichurus lepturus, Terapon puta, Otolithes ruber, Eubleekeria splendens, Siganus oramin, Carangoides malabaricus and Selaroides leptolepsis [22, 8, 23], Thunnus obesus, Decapterus russelli, Megalaspis cordyla, Terapon jarbua, Escualosa thoracata, Anodontostoma chacunda, Sardinella albella, Amblygaster clupeoides, Amblygaster sirm, Sardinella melanura, Ilisha megaloptera, Tenualosa toil, Pampus argenteus, Pampus chinensis, Himantura bleekeri, Megalops cyprinoides, Plicofollis tenuispinis, Hemiramphus far, Strongylura strongylura, Strongylura leiura, Tylosurus acus melanotus, Tylosurus crocodilus crocodilus, Leiognathus bindus, Cynoglossus dubius, Cynoglossus arel, Lepturacanthus savala, Mugil cephalus, Sphyraena forsteri, Lutjanus johni, Lutjanus malabaricus, Cypselurus oligolepis, Chanos chanos, Scoliodon palasorra and Chiloscyllium indicum [24], Lithognathus mormyrus [25], Gymnothorax eurostus, Thryssa malabarica, Thryssa setirostris, Coilia dussumieri, Opisthopterus tardoore, scualosa thoracata and Ambassis ambassis [26], Sphyraena japonica, Trachurus japonicas, and Etrumeus micropus [27]. The genus Nerocila were reported so far from the different parts of the world including North America, Mediterranean Sea, California, eastern Pacific, Hong Kong and Australia, Yugoslavia, Kuwait, Adriatic Sea, Indo-West Pacific, Malaysia, Turkey, Lebanon, Algeria and India, and now this genus range was extending from Andaman Islands [ 24].
Parasitic isopods are typically marine and usually inhabit the warmer seas [28]. These large aquatic organisms are commonly found on the external surfaces, inside the buccal cavity, or in the branchial cavity of their fish host. Parasitic isopod appendages are highly modified especially hook like legs to hold the body surface and tearing the strong body muscles and sucking the body fluids with the help of piercing and sucking mouth parts of the host fish. Kabata (1985) observed destruction of host tissues as a result of the pressure exerted by the parasite. Segal (1987) observed that the host fish, Meniida beryllina died due to attack of isopod Nerocila acuminata. Alas et al. (2008) studying the Cymothoid Nerocila bivittata on the fish Parablennius sanguinolentus (Perciformes, Blenniidae) in the Samsun coast of the Black Sea, found a prevalence of $7.4 \%$ and registered Portunus sanguinolentus as a new host for the $N$. bivittata. At present, fish parasites and diseases are one of the most important problems confronted by the fishery biologists [32]. Most of the parasitological studies and parasitic researchers are showing more interest towards the study of parasitic forms because they are an important component in global biodiversity and their diversity is gradually increasing [33]. The study of parasitic species associated with economically valuable fishes is an important area of research that contributes to the successful and sustainable management of fisheries and aquaculture systems throughout the world [34].

\section{Conclusion}

Knowledge of fish diseases and parasites is essential in Indian coastal regions particularly from Andaman and Nicobar Islands with long and highly productive coastal waters. Andaman waters are rich in fish population which are vital component in the food web, and plays a major role by providing economic value for food, aquarium use, recreation, and ecology of water system. Due to its remoteness and lack of research, only few reports of parasitic isopods have been made on commercially important marine fishes from Andaman and Nicobar Islands. In the present study, we reported new host record of the fish $L$. gibbus infected by the isopod parasite Nerocila sp. for the first time from the coastal waters of South Andaman, Andaman Islands. This study added one more isopoda 
species to the isopoda check list of Andaman and Nicobar Islands.

\section{Acknowledgment}

The authors are thankful to the Pondicherry University for providing the necessary fund and lab facilities to carry out this present study. First author also grateful to Dr. Niel L. Bruce, Senior Curator at the Museum of Tropical Queensland in Townsville, Australia for his help by providing the valuable identification keys and tips.

\section{References}

1. Tavares-Dias M, Araújo CSO, Barros MS, Viana GM (2014) New Hosts and Distribution Records of Braga Patagonica, a parasite Cymothoidae of fishes from the Amazon. Brazilian Journal of Aquatic Science and Technology 18 (1): 91 - 97.

2. Peninal S, Sathiya Rathna G, Elavarasi A, Kalaiselvam M (2014) First report on the record of parasitic infection in the Moray eel (Thyrsoidea macrura) along the Parangipettai coastal waters (Southeast coast of India). Journal of Parasitic Diseases 38 (3): 273-276. doi: 10.1007/s12639-012-0227-8.

3. Bharadhirajan P, Murugan S, Sakthivel A, Selvakumar P (2014) Isopods parasites infection on commercial fishes of Parangipettai waters, southeast coast of India. Asian Pacific Journal of Tropical Disease 4 (1): 268 - 272. doi: 10.1016/S2222 1808(14)60453-9.

4. Smit NJ, Bruce NL, Hadfield KA (2014) Global diversity of fish parasitic isopod crustaceans of the family Cymothoidae. International Journal for Parasitology: Parasites and Wildlife 3(2):188-197. doi: 10.1016/j.jppaw.2014.03.004.

5. Rameshkumar G, Ravichandran S (2010) New Host Record, Rastrelliger kanagurta, for Nerocila phaeopleura Parasites (Crustacea, Isopoda, Cymothoidae. Middle-East Journal of Scientific Research 5 (1): 54-56.

6. Trilles JP, Rameshkumar G, Ravichandran S (2011) A checklist of the Cymothoidae (Crustacea, Isopoda) recorded from Indian fishes. Acta Parasitologica 56 (4): 446 - 459. doi: 10.2478/s11686-011-0077-z.

7. Ramdane Z, Bensouilah MA, Trilles JP (2007) The Cymothoidae on marine fishes, from Algerian fauna. Belgian Journal of Zoology 137(1): 67-74.

8. Rameshkumar G, Ravichandran S, Sivasubramanian K, Trilles JP (2013) New occurrence of parasitic isopods from Indian fishes. Journal of Parasitic Diseases 37(1): 42-46. doi: 10.1007/s12639-012-0128-x.

9. Satyanarayan S (2012) Occurrence of isopod parasites in clupeids off Chennai coast, India. Indian Journal of Fisheries 59(3): 153-155.
10. Seth JK, Sahoo S, Mitra S (2014) First Record of Isopod parasite, Nerocila phaeopleura on the host fish Rastrelliger kanagurta collected from Bay of Bengal, Odisha coast, India. International Journal of Current Research 6 (4): 6092 - 6093.

11. Fischer W, Bianchi G, eds. (1983) FAO species identification sheets for fishery purpose, Western Indian Ocean, Italy.

12. Bruce NL (1987) Australian species of Nerocila Leach, 1818, and Creniola n.gen. (Isopoda: Cymothoidae), Crustacean Parasites of Marine Fishes. Records of the Australian Museum 39:355-412.

13. Pillai NK (1954) A preliminary note on the Tanaidacea and Isopoda of Travancore. Bulletin of the Central Research Institute, University of Travancore 3 (1): 1 - 21.

14. Hadfield KA, Bruce NL, Smit NJ (2010) Redescription of the monotypic genus Cinusa Schioedte \& Meinert, 1884 (Isopoda, Cymothoidae), a buccal cavity isopod from South Africa. Zootaxa 2437:51-68.

15. Praveenraj J, Saravanan K, Puneeth Kumar P, Dam Roy S (2016) First record on the occurrence of Ryukyua circularis (Pillai, 1954) a parasitic cymothoid (Crustacean: Isopoda) infesting the clupeid fish Amblygaster sirm (Walbaum) from Andaman Islands, India. Journal of Parasitic Diseases 41 (2): 593 - 595. doi: 10.1007/s12639-016-0823-0.

16. Jithin K, Swapna A, Kumar RR et al. (2016) Studies on Crustacean parasites from commercial marine fish along the Andaman Coast in comparison with Malabar Coast of Kerala of Indian EEZ. World Journal of Fish and Marine Sciences 8 (1): 47 - 53. doi:10.5829/idosi.wjfms.2016.8.1.10245.

17. Anil P, Das T, Jayaraj KA (2018) New record of marine parasitic isopods (Family, Corallinidae) from South Andaman, Andaman Islands, India. Journal of Tropical Life Science 8 (3): 295 - 302.doi: 10.11594/jtls.08.03.12.

18. Bruce NL, Harrison-Nelson EB (1988) New records of fish parasitic marine isopod crustaceans (Cymothoidae, subfamily Anilocrinae) from the Indo-West Pacific. Proceedings of the Biological Society of Washington 101 (3): 585-602.

19. Bowman TE, Tareen IU (1983) Cymothoidae from fishes of Kuwait (Arabian Gulf) (Crustacea: Isopoda). Smithsonian Contributions to Zoology 382: 1 - 30.

20. Bunkley-Williams L, Williams EH JR, Bashirullah AKM (2006) Isopods (Isopoda: Aegidae, Cymothoidae, Gnathiidae) associated with Venezuelan marine fishes (Elasmobranchii, Actinopterygii). Revista de Biología Tropical 54 (3): 175 - 188.

21. Trilles JP, Rameshkumar G, Ravichandran S (2013) Nerocila species (Crustacea, Isopoda, Cymothoidae) from Indian marine fishes. Parasitology Research 112 (3): 1273 - 1286. doi: 10.1007/s00436-012-3263-5.

22. Rameshkumar G, Ravichandran S, Trilles JP (2011) Cymothoidae (Crustacea, Isopoda) from Indian fishes. Acta Parasitologica 56 (1): 78 -9 1. doi: 10.2478/s11686-011-0002-5. 
23. Rameshkumar G, Ravichandran S, Ramesh M (2014) Distribution of isopod parasites in Carangid fishes from Parangipettai, Southeast coast of India. Journal of Parasitic Diseases 40 (1): 124 - 128. doi: 10.1007/s12639-014-0460-4.

24. Aneesh PT, Sudha K, Arshad K et al. (2013) Seasonal fluctuation of the prevalence of cymothoids representing the genus Nerocila (Crustacea, Isopoda), parasitizing commercially exploited marine fishes from the Malabar Coast, India. Acta Parasitologica 58 (1): 80 - 90. doi: 10.2478/s11686-013-0112-3.

25. Samn AA, Metwally KM, Zeina AF, Khalaf Allah HM (2014) First occurrence of Nerocila bivittata: Parasitic Isopods (skin shedders) on Lithognathus mormyrus (Osteichthyes, Sparidae) from Abu Qir Bay, Alexandria, Egypt. Journal of American Science 10 (7): $171-197$.

26. Aneesh PT, Sudha K, Helna AK et al. (2015) Cymothoa frontalis, a cymothoid isopod parasitizing the belonid fish Strongylura strongylura from the Malabar Coast (Kerala, India): redescription, description, prevalence and life cycle. Zoological Studies 54: 42. doi: 10.1186/s40555-015-0118-7.

27. Nagasawa K, Isozaki S (2017) Three new host records for the marine fish ectoparasite, Nerocila phaiopleura (Isopoda: Cymothoidae), with a list of its known hosts. Crustacean Research 46: $153-159$.
28. Rameshkumar G, Ravichandran S (2014) Problems caused by isopod parasites in commercial fishes. Journal of Parasitic Diseases 38 (1): 138 - 141. doi: 10.1007/s12639-012-0210-4.

29. Kabata Z (1985) Parasites and disease of fish cultured in Tropics. Volume 91 Issue 3. London, Taylor and Francis.

30. Segal E (1987) Behaviours of juvenile Nerocila acuminata (Isopoda: Cymothoidae) during attack and attachment and feeding on fish prey. Bulletin of Marine Science 41 (2): 351 - 360

31. Alas A, Öktener A, Iscimen A, Trilles JP (2008) New host record, Parablennius sanguinolentus (Teleostei, Perciformes, Blenniidae) for Nerocila bivittata (Crustacea, Isopoda, Cymothoidae). Parasitology Research 102 (4): 645 - 646.

32. Ravichandran S, Balasubramanin T, Kannupandi T (2007) Incidence of parasitic isopods on the fish Sphyraena obtusata. Research Journal of Parasitology 2: 45 - 50.

33. Poulin R, Morand S (2004) Parasite biodiversity. Washington D.C., Smithsonian Institute Scholarly Press,

34. Reed CC (2015) A review of parasite studies of commercially important marine fishes in sub-Saharan Africa. Parasitology 142: 109 - 124. doi:10.1017/S0031182014000390. 